\title{
KORELASI KEMAMPUAN PENGELOLAAN LABORATORIUM DAN HASIL BELAJAR PADA MATA KULIAH PENGELOLAAN LABORATORIUM
}

\author{
Irwan Susanto \\ Dosen Prodi Pendidikan Fisika FKIP Universitas Darma Agung; Medan \\ Email : irwansusantosaragih@gmail.com
}

Diterima 25 Mei 2017, disetujui untuk publikasi 20 Juli 2017

\begin{abstract}
Abstrak Penelitian ini bertujuan untuk mengetahui korelasi kemampuan pengelolaan laboratorium dan hasil belajar pada mata kuliah pengelolaan laboratorium. Jenis penelitian ini adalah deskriptif korelasional. Instrumen pengambilan data dalam penelitian ini adalah dokumentasi dan angket yang berjumlah 18 item. Sebelum angket digunakan terlebih dahulu diuji cobakan di luar sampel untuk mengetahui validitas dan reliabilitas angket. Berdasarkan uji normalitas data berdistribusi normal. Uji linearitas hubungan kemampuan pengelolaan laboratorium dengan hasil belajar pada mata kuliah pengelolaan laboratorium fisika dengan uji Ramsay test diperoleh data adalah linear. Berdasarkan uji kecenderungan diperoleh kecenderungan kemampuan pengelolaan laboratorium sangat tinggi (50\%) dan hasil belajar mata kuliah pengelolaan laboratorium mahasiswa fisika kategori cenderung sangat tinggi (45\%). Berdasarkan hasil uji hipotesisndengan SPSS diperoleh bahwa ada korelasi kemampuan pengelolaan laboratorium dan hasil belajar pada mata kuliah pengelolaan laboratorium.
\end{abstract}

\author{
Kata Kunci: \\ Pengelolaan \\ Laboratorium, \\ Korelasi, Hasil \\ Belajar
}

\section{Pendahuluan}

Peningkatan kualitas sumber daya manusia merupakan salah satu penekanan dari tujuan pendidikan, seperti yang tertuang dalam UU No.20 Tahun 2003 tentang tujuan Pendidikan Nasional Bab II Pasal 3 yang berbunyi:"Pendidikan Nasional berfungsi mengembangkan kemampuan dan membentuk watak serta peradaban bangsa yang bermartabat dalam rangka mencerdaskan bangsa, bertujuan untuk berkembangnya potensi peserta didik agar menjadi manusia yang beriman dan bertaqwa kepada Tuhan Yang Maha Esa, beraklak mulia, berilmu, cakap, kreatif, mandiri dan menjadi warga Negara yang demokratis serta bertanggung jawab". Untuk mencapai sumber daya manusia yang berkualitas tentunya didukung sistem pendidikan yang berkualitas.

Pendidikan adalah usaha sadar dan terencana untuk mewujudkan suasana belajar dan proses pembelajaran agar mahasiswa secara aktif mengembangkan potensi dirinya untuk memiliki kekuatan spiritual keagamaan, pengendalian diri, kepribadian, kecerdasan, akhlak mulia, serta keterampilan yang diperlukan dirinya, masyarakat, bangsa dan negara. 
Oleh karena itu pendidikan selalu menjadi prioritas. Hal ini sesuai dengan undangundang No. 20 Tahun 2003 Bab II Pasal 3 yang menyatakan: Pendidikan berfungsi mengembangkan kemampuan dan membentukwatak serta peradapan bangsa yang bermartabat dalam rangka mencerdaskan kehidupan bangsa. Pendidikan bertujuan untuk mengembangkan potensi peserta didik agar menjadi manusia yang beriman dan bertaqwa kepada Tuhan Yang Maha Esa, berahlak mulia, sehat, berilmu, cakap, kreatif, mandiri, dan menjadi warga negara yang demokratis serta bertanggung jawab" (Trianto, 2014).

Dalam aktivitas kehidupan manusia sehari-hari hampir tidak pernah dapat terlepas dalam kegiatan belajar, baik ketika seseorang melaksanakan aktivitas sendiri, maupun didalam suatu kelompok tertentu. Dipahami ataupun tidak dipahami sesungguhnya sebagian besar aktivitas dalam kehidupan sehari-hari kita merupakan kegiatan belajar. Dengan demikian dapat kita katakan, tidak ada ruang dan waktu dimana manusia dapat melepaskan dirinya dari kegiatan belajar, dan itu berarti belajar tidak pernah dibatasi usia, tempat maupun waktu, karena perubahan yang menurut terjadinya aktivitas belajar itu juga tidak pernah berhenti. Menurut Purwanto (2011:38) menyatakan bahwa: "Belajar merupakan proses dalam diri individu yang berinteraksi dengan lingkungan untuk mendapatkan perubahan dalam perilakunya".Menurut Abdillah dalam Aunurrahman (2012) menyatakan bahwa : "Belajar adalah suatu usaha sadar yang dilakukan oleh individu dalam perubahan tingkah laku baik melalui latihan dan pengalaman yang menyangkut aspekaspek kognitif, afektif dan psikomotorik untuk memperoleh tujuan tertentu".

Keberhasilan dalam belajar dapat dilihat dari berbagai aspek penilaian. Menurut Mudjiono (2011) menyatakan bahwa : "Hasil belajar merupakan hasil dari suatu interaksi tindak belajar dan tindak mengajar. Dari segi guru tindak mengajar diakhiri dengan proses evaluasi hasil belajar. Dari segi mahasiswa hasil belajar merupakan berakhirnya puncak proses belajar". Menurut Sudjana (2011) menyatakan bahwa : "Hasil belajar adalah kemampuan-kemampuan yang dimiliki mahasiswa setelah dia menerima pengalaman belajar". Keberhasilan atau kegagalan dalam proses belajar mengajar merupakan sebuah ukuran atas proses pembelajaran. Menurut Sutikno dalam Istarani (2010) mengatakan bahwa, "Belajar dikatakan berhasil apabila diikuti ciri-ciri 1) daya serap terhadap bahan pengajaran yang diajarkan mencapai prestasi tinggi, baik secara individu maupun kelompok, 2) perilaku yang digariskan dalam tujuan pengajaran khusus telah dicapai oleh mahasiswa baik secara individu maupun secara kelompok, 3) terjadinya proses pemahaman materi yang secara sekuensial mengantarkan materi terhadap berikutnya".

Kegiatan pembelajaran terutama ditingkat mahasiswa sering sekali tidak terlepas dari mata kuliah yang berkaitaan dengan laboratorium untuk kegiatan praktikum/percobaan. Dalam Kamus

Besar Bahasa Indonesia (Poerwadarminta, 2002) laboratorium diartikan sebagai tempat mengadakan percobaan (penyelidikan dan sebagainya). Menurut (Decaprio, 2013) laboratorium yang sering di singkat "lab" adalah tempat di lakukannya riset (penelitian) ilmiah, eksperimen (percobaan), pengukuran, ataupun pelatihan ilmiah. Sekolah sebagai suatu lembaga kependidikan diwajibkan memiliki sarana dan prasarana penunjang untuk proses pembelajaran sehingga dapat mencapai tujuan pembelajaran.

Laboratorium sebagai tempat kegiatan riset, penelitian, percobaan, pengamatan, serta pengujian ilmiah memiliki banyak fungsi. Berikut ini beberapa fungsi laboaratorium yang paliang utama (Decaprio, 2013) adalah; 1) 
menyeimbangkan antara teori dan praktik ilmu dan menyatukan antara teori dan praktek. Laboratorium adalah tempat untuk meguji sebuah teori yang telah di terima secara langsung dalam konteks itu, keduanya akan saling melengkapi, yaitu teori akan dapat menjadi pijakan (dasar) praktik dan penelitian, sedangkan penelitian akan menguatkan argumentasi teori, 2) memberikan keterampilan kerja ilmiah bagi para peneliti, baik dari kalangan peserta didik, mahapeserta didik, guru, dosen, ataupun peneliti lainnya. Hal ini di sebabkan laboratorium tidak hanya menuntut pemahaman terhadap objek yang di kaji, tetapi juga menuntut seseorang untuk melakukan sebuah eksperimentasi, 3) laboratorium dapat menjadi sumber untuk memecahkan berbagai masalah melalui kegiatan praktik, baik itu masalah dalam pembelajaran, masalah akademik, maupun masalah yang terjasi di tengah masayarakat yang membutuhkan pengamana dengan uji laboratoium, 4) laboratorium dapat menjadi sarana belajar bagi para peserta didik, mahapeserta didik, dosen, aktivis, peneliti, dan lain lain untuk memhami segala ilmu pengetahuan yang bersifat abstrak sehingga menjadi sesuatu yang bersifat konkret dan nyata, 5) menambah keterampilan dan keahlian para peneliti dalam mempergunkan alat media yang tersedia di dalam laboratorium untuk mencari dan menentukan kebenaran ilmiah sesuai dengan berbagai macam riset atau pun eksperimentasi yang akan dilakukan.

Pengelolaan laboratorium tentu saja bukan semata mata di tunjukkan untuk tujuan tujauan komersial. Pada umumnya, pengelolaan laboratorium di dasarkan terhadap beberapa hal pokok yang akan dilaksanakan (Decaprio, 2013), yaitu; 1) laboratorium harus di kelola dan di rancang untuk menumbuhkan dan mengembangkan keterampilan para penggunanya dalam berbagai kegiatan praktik, 2) laboratorium harus dikelola dan dirancang untuk melatih kemampuan menyusun dan menganalisis hasil pengamatan, yang kemudian di lanjutkan untuk menafsirkan hasil pengamatan, 3) laboratorium harus di kelola dan di rancang untuk melatih kemampuan membuat kesmpulan logis, 4) laboratorium harus di kelola dan dirancang untuk melatih kemampuan mengomunikasikan hasil kegiatan praktik, 5) laboratorium harus dikalola dan di rancang untuk melatih keterampilan merancang kegiatan praktik dan melaksanakannya, 6) laboratorium harus dikelola dan di rancang secara fleksibel serta tidak menekan siapa saja yang terlibat di dalamnya, 7) peran laboratorium dalam pembelajaran pengelolaan laboratorium.

\section{Metode Penelitian}

Penelitian ini dilaksanakan di FKIP UDA pada Program Studi Pendidikan Fisika yang berlokasi di Jalan TD. Pardede No. 21 Medan. Data penelitian dalam penelitian diambil dari populasi yang telah ditentukan.

Arikunto (2013) mengatakan bahwa: "populasi adalah keseluruhan subjek penelitian". Populasi dalam penelitian ini adalah seluruh mahasiswa Prodi Pendidikan Fisika FKIP UDA sebanyak 20 mahasiswa. Sampel dalam penelitian ini adalah mahasiswa semester IV prodi pendidikan fisika FKIP UDA yang berjumlah 20 orang.

Dalam hal ini penelitian terdiri dari dua variabel penelitian, yaitu: 1) Variabel bebas adalah merupakan variabel yang mempengaruhi atau yang menjadi sebab perubahannya atau timbulnya variabel terikat (Sugiyono 2011). Dalam penelitian ini yang menjadi variabel bebas adalah pengelolaan laboratorium (Variabel X), 2) Variabel terikat $(\mathrm{Y})$ adalah variabel yang di pengaruhi atau menjadi akibat, karena adanya variabel bebas. Variabel terikat dalam penelitian ini adalah hasil belajar mahasiswa dengan indikator hasil tes/nilai harian praktek mahasiswa semester IV 
Pendidikan Fisika pada mata kuliah pengelolaan laboratorium di FKIP UDA.

\section{Hasil Penelitian dan Pembahasan}

Hasil penelitian tentang kemampuan pengelolaan laboratorium pada mata kuliah pengelolaan laboratorium yang telah dikonversikan dalam bentuk nilai dapat dilihat pada Tabel 1;

Tabel 1. Deskripsi Nilai Kemampuan Pengelolaan Laboratorium

\begin{tabular}{lrr}
\hline $\mathrm{N}$ & Valid & 20 \\
\cline { 2 - 3 } & Missing & 20 \\
\hline Mean & & 78.9375 \\
\hline Median & 83.1250 \\
\hline Std. Deviation & 9.18805 \\
\hline Variance & 84.420 \\
\hline
\end{tabular}

Sedangkan data hasil belajar mahasiswa semester IV Prodi Pendidikan Fisika FKIP UDA pada mata kuliah Pengelolaan laboratorium dapat dilihat pada Tabel 2;

Tabel 2. Deskripsi Nilai Hasil Belajar Mata Kuliah Pengelolaan Laboratorium

\begin{tabular}{lll}
\hline $\mathrm{N}$ & Valid & 20 \\
\cline { 2 - 3 } & Missing & 20 \\
\hline Mean & 85.0000 \\
\hline Median & 85.0000 \\
\hline Std. Deviation & 7.77987 \\
\hline Variances & 60.526 \\
\hline
\end{tabular}

Sebelum dilakukan uji korelasi, terlebih dahulu dilakukan uji persyaratan analisis, yaitu uji Chi Square dan uji linieritas. Uji normalitas bertujuan untuk mengetahui apakah data yang diperoleh dari hasil penelitian berdistribusi normal atau tidak (Arikunto, 2013). Pengujian uji normalitas dalam penelitian ini dilakukan pada kedua variabel dengan menggunakan SPSS. Adapun hasil pengujian normalitas data dapat dilihat pada Tabel 3 dan Tabel 4;

Tabel 3. Hasil Uji Normalitas Kemampuan Pengelolaan Laboratorium

\begin{tabular}{lc}
\hline Chi-Square & $5.200^{\mathrm{a}}$ \\
\hline Df & 13 \\
\hline Asymp. Sig. & .971 \\
\hline
\end{tabular}

a. 14 cells $(100.0 \%)$ have expected frequencies less than 5 . The minimum expected cell frequency is 1.4.
Berdasarkan tabel di atas diperoleh harga sign (2-tiled) $=0,971$ dan $\alpha=0,05$, karena sign $<\alpha(0,971>0,05)$ berarti data berditribusi normal.

Tabel 4. Hasil Uji Normalitas Hasil Belajar Pengelolaan Laboratorium

\begin{tabular}{lc}
\hline Chi-Square & $5.200^{\mathrm{a}}$ \\
\hline Df & 13 \\
\hline Asymp. Sig. & .971 \\
\hline $\begin{array}{l}\text { a. } 14 \text { cells (100.0\%) have expected frequencies less } \\
\text { than 5. The minimum expected cell frequency is 1.4. }\end{array}$
\end{tabular}

Berdasarkan tabel di atas diperoleh, bahwa harga sign (2-tiled) $=0,467$ dan $\alpha=$ 0,05 , karena sign< $\alpha \quad(0,971>0,05)$ berarti data berditribusi normal. Uji linieritas dilakukan untuk mengetahui linier tidaknya hubungan anatara variabel bebas dan variabel terikat (Wiratna, 2015). Adapun hail uji linier antara kedua variabel dapat dilihat pada Tabel 5;

Tabel 5. Hasil Uji Linieritas

\begin{tabular}{lccc}
\hline Nilai_Gabungan & & & \\
\hline Levene Statistic & df1 & df2 & Sig. \\
\hline 1.794 & 1 & 38 & .188 \\
\hline
\end{tabular}

Berdasarkan tabel di atas diperoleh, bahwa harga sign (2-tiled) $=0,188$ dan $\alpha=$ 0,05 , karena nilai sign $>\alpha \quad(0,188>0.05)$ berarti data linear.

Tabel 6. Hasil Uji Korelasi Kemampuan Pengelolaan Laboratorium dan Hasil Belajar Mata Kuliah Pengelolaan Laboratorium

\begin{tabular}{|c|c|c|c|}
\hline & & $\begin{array}{l}\text { Kem. } \\
\text { Peng. Lab }\end{array}$ & $\begin{array}{l}\text { H- } \\
\text { B_P.Lab }\end{array}$ \\
\hline \multirow{4}{*}{$\begin{array}{l}\text { Kem. } \\
\text { Peng. } \\
\text { Lab }\end{array}$} & Pearson & 1 &, $396^{*}$ \\
\hline & Correlation & & \\
\hline & $\begin{array}{l}\text { Sig. (2- } \\
\text { Tiled }\end{array}$ & & ,031 \\
\hline & $\mathrm{N}$ & 20 & \\
\hline \multirow{4}{*}{$\begin{array}{l}\text { H- } \\
\text { B_P.Lab }\end{array}$} & Pearson & $396^{*}$ & 1 \\
\hline & Correlation & & \\
\hline & $\begin{array}{l}\text { Sig. (2- } \\
\text { Tiled }\end{array}$ & ,031 & \\
\hline & $\mathrm{N}$ & 20 & 20 \\
\hline
\end{tabular}


Jika dibandingkan dengan $\alpha=0,05$, nilai signifikansi lebih dari pada nilai Sig. (2tiled), yaitu $0,031 \leq 0,05$. Hal ini menunjukkan bahwa ada korelasi antara kemampuan pengelolaan laboratorium dan hasil belajar pada mata kuliah pengelolaan laboratorium mahasiswa semester IV Prodi Pendidikan Fisika FKIP UDA.

Laboratorium merupakan tempat proses belajar mengajar dengan aktivitas praktikum yang melibatkan interaksi antara mahasiswa, peralatan, dan bahan. Menurut Handayani (2010) laboratorium adalah tempat belajar mengajar melalui metode praktikum yang dapat menghasilkan pengalaman belajar dimana mahasiswa berinteraksi dengan berbagai alat dan bahan untuk mengobservasi gejala-gejala yang dapat diamati secara langsung dan membuktikan sendiri suatu yang dipelajari.

Selain secara fisik laboratorium, peran mahasiswa juga harus memiliki kemampuan atau kompetensi yang diharapkan ada adalah kemampuan manajerial dan kemampuan individual dalam merencanakan, mengorganisasikan, melaksanakan dan mengevaluasi segala kegiatan yang berhubungan dengan pembelajaran di laboratorium. Namun kenyataannya masih ada mahasiswa yang kurang pelatihan dalam penggunaan laboratorium, sehingga guru kurang aktif dalam pelaksanaan kegiatan praktikum di laboratorium. Selain itu, sikap mahasiswa juga turut memegang peran penting dalam berlangsungnya proses pembelajaran di laboratorium. Dalam pelaksanaan kegiatan praktikum sangat antusias untuk mengikuti dan melakukan percobaan di laboratorium. Dalam pelaksanaan kegiatan praktikum administrasi alat praktikumnya telah dipersiapkan.

Agar laboratorium IPA di sekolah dapat berperan, berfungsi dan bermanfaat, maka diperlukan sebuah sistem pengelolaan laboratorium yang direncanakan dan dievaluasi dengan baik serta dilaksanakan oleh semua pihak yang terkait dengan penyelenggaraan laboratorium fisika di program studi pendidikan fisika FKIP UDA. Dimensi pengelolaan laboratorium terdiri dari: Organisasi Laboratorium; Administrasi Laboratorium (inventarisasi alat dan fasilitas laboratorium, administrasi penggunaan laboratorium, administrasi peminjaman alat-alat laboratorium, administrasi pemeliharaan alat-alat laboratorium); Keselamatan kerja di laboratorium (Sutrisno, 2010)

Berdasarkan hasil penelitian antara kemampuan pengelolaan kemampuan mahasiswa dengan nilai hasil belajar mata kuliah pengelolaan laboratorium diperoleh hasil hubungan yang signifikan. Hasil ini sependapat dengan hasil penelitian Katili, dkk (2013) bahwa, penggunaan dan kontribusi laboratorium serta kemampuan pengelolaan laboratorium mahasiswa berhubungan positif terhadap hasil belajar mahasiswa. Artinya, dengan penggunaan fasilitas laboratorium dan kemampuan pengelolaan mahasiswa dalam laboratorium akan meningkatkan hasil belajar mahasiswa terlebih pada mata kuliah yang memiliki praktikum.

\section{Simpulan dan Saran}

Berdasarkan hasil analisis data dalam penelitian maka peneliti dapat mengambil kesimpulan, yaitu: (1) kecenderungan Pengelolaan Laboratorium mahasiswa semester IV Fisika Universitas Darma Agung adalah kategori tinggi (55\%), (2) kecenderungan hasil belajar Pengelolaan laboratorium mahasiswa semester IV Fisika Universitas Darma Agung adalah dengan kategori tinggi (45\%), (3) ada korelasi yang signifikan antara pengelolaan laboratorium dengan hasil belajar mata kuliah pengelolaan laboratorium fisika mahasiswa semester IV Universitas Darma Agung.

Berdasarkan hasil penelitian pengelolaan laboratorium fisika Universitas Darma Agung, maka dapat dijadikan acuan 
atau masukan untuk penelitian tindak lanjut diantaranya: (1) dapat dilakukan penelitian lanjut tentang desain ruang laboratorium fisika yang memenuhi standar kelayakan laboratorium, (2) dapat dilakukan penelitian yang sejenis dengan lokasi yang berbeda dengan memperhatikan kelengkapan sarana dan prasarana laboratorium sehingga memudahkan terlaksananya pelaksanaan penelitian,

\section{Daftar Pustaka}

Aunurrahman, 2012. Belajar dan Pembelajaran, Bandung: Alfabeta.

Arikunto., 2016. Dasar-dasar Evaluasi Pendidikan. Penerbit Bumi Aksara, Jakarta.

Decaprio Richard., 2013. Tips Mengelola Laboratorium Sekolah, DIVA Press. Yogyakarta

Dimyati dan Mudjiono, 2006. Belajar Dan Pembelajaran, Rineka Cipta, Jakarta.

Istarani. 2010. 58 Model Pembelajaran Inovatif. Medan: Media Persada.

Made, Dkk .2015. Analisis Sarana Sarana Dan Intensitas Peggunaan Laboratorium Terhadap Keterampilan Sains Siswa SMA Negeri Se-Kota Tanjung Balai. Jurnal Tabularasa PPS Unimed Vol.12 No.1, Diakses 20 April 2016.

Mahfudiani Fauzul Chrisma., 2015. Evektifitas pemanfaatan laboratorium IPA. Skripsi. Yogyakarta.

Meillani Pipit., 2015. Pengaruh pemanfaatan laboratorium terhadap hasil belajar siswa pada kompetensi dasar. Skripsi. Semarang.

Purwanto., 2013. Evaluasi Hasil Belajar. Pustaka Belajar, Yogyakarta.

Slameto., 2016. Belajar dan Faktor - faktor yang mempengaruhinya. PT Rineka Cipta: Jakarta.

Sugiono., 2011. Metode Penelitian Pendidikan. Penerbit Alfabeta, Bandung.

Sujarweni Wiratna V., 2015. SPSS Untuk Penelitian. PT Rineka Cipta. Bandung.
Sudjana, N. 2011. Penilaian Hasil dan Proses Belajar Mengajar. Bandung: Rosda Karya.

Sutrisno, E. 2010. Manajemen Sumber Daya Manusia, Cetakan Kelima. Yogyakarta: Prenada Media

Trianto. 2014. Model Pembelajaran Terpadu. Jakarta: Bumi Aksara. 